\title{
The Distributive Impact Assessment Model (DIAM): Technology Share Component
}




\section{Argonne National Laboratory}

Argonne National Laboratory, with facilities in the states of Illinois and Idaho, is owned by the United States Government, and operated by the University of Chicago under the provisions of a contract with the Department of Energy.

This technical memo is a product of Argonne's Energy Systems (ES) Division. For information on the division's scientific and engineering activities, contact:

\section{Director, Energy Systems Division}

Argonne National Laboratory

Argonne, Illinois 60439-4815

Telephone (708) 252-3724

Presented in this technical memo are preliminary results of ongoing work or work that is more limited in scope and depth than that described in formal reports issued by the ES Division.

Publishing support services were provided by Argonne's Information and Publishing Division.

\section{Disclaimer}

This report was prepared as an account of work sponsored by an agency of the United States Government. Neither the United States Government nor any agency thereof, nor any of their employees, makes any warranty, express or implied, or assumes any legal liability or responsibility for the accuracy, completeness, or usefulness of any information, apparatus, product, or process disclosed, or represents that its use would not infringe privately owned rights. Reference herein to any specific commercial product, process, or service by trade name, trademark, manufacturer, or otherwise, does not necessarily constitute or imply its endorsement, recommendation, or favoring by the United States Government or any agency thereof. The views and opinions of authors expressed herein do not necessarily state or reflect those of the United States Government or any agency thereof.

Reproduced directly from the best available copy.

Available to DOE and DOE contractors from the Office of Scientific and Technical Information, P.O. Box 62, Oak Ridge, TN 37831; prices available from (615) 576-8401. 


\section{DISCLAIMER}

Portions of this document may be illegible in electronic image products. Images are produced from the best available original document. 


\section{The Distributive Impact Assessment Model (DIAM): Technology Share Component}

by D.A. Poyer, E. Earl, and B. Bonner

Energy Systems Division,

Argonne National Laboratory, 9700 South Cass Avenue, Argonne, Illinois 60439

March 1995

Work sponsored by United States Department of Energy,

Office of Economic Impact and Diversity

DISTRIBUTION OF THIS DOCUMENT IS UNLIMITED<smiles>CC1CCCCC1</smiles> 
G今

This report is printed on recycled paper. 


\section{CONTENTS}

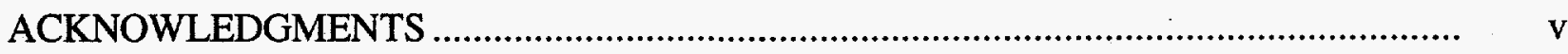

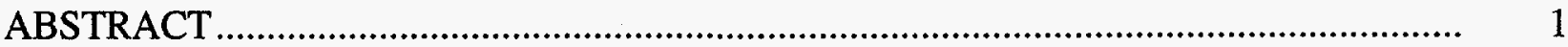

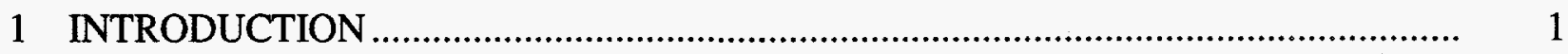

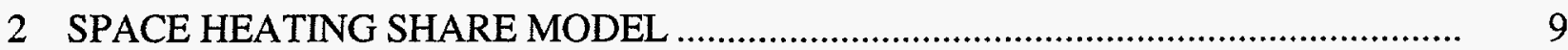

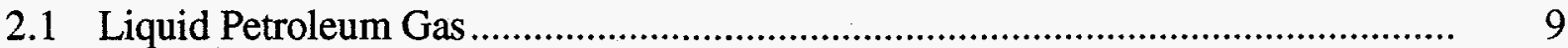

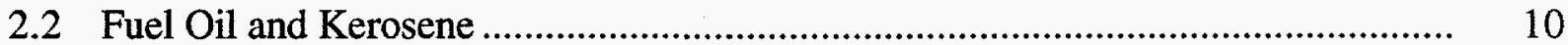

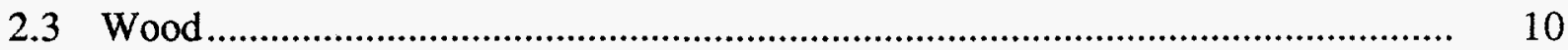

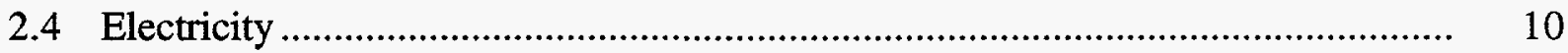

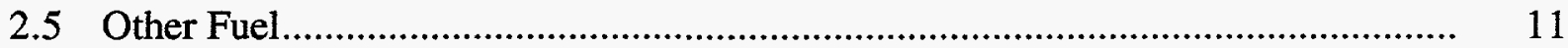

3 WATER HEATING SHARE MODEL .........................................................

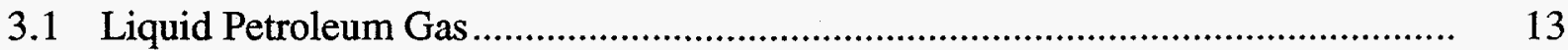

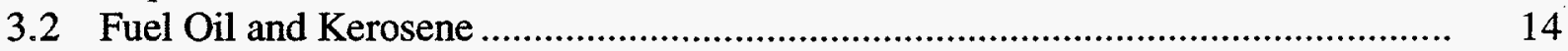

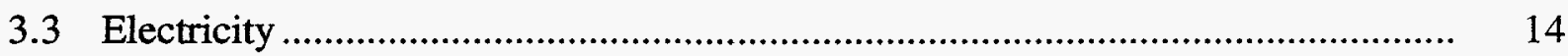

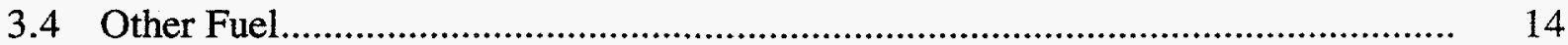

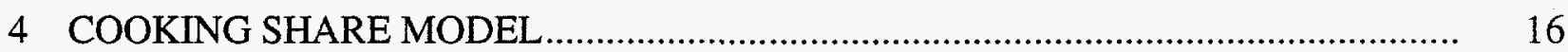

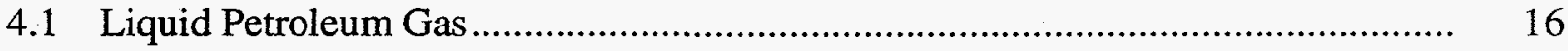

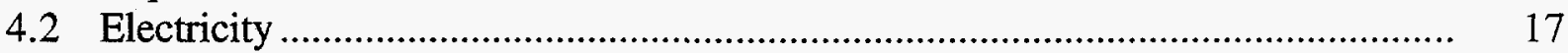

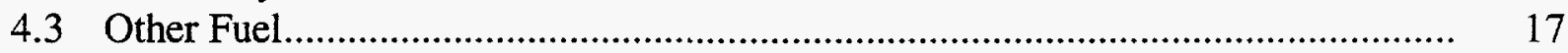

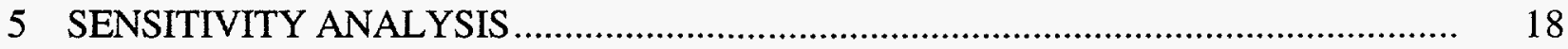

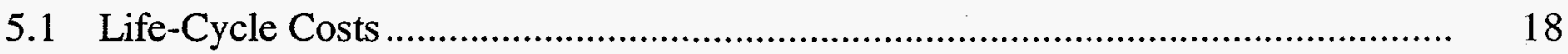

5.2 Income Quintile Shares .............................................................................. 22

5.3 Back-Casting ................................................................................... 22

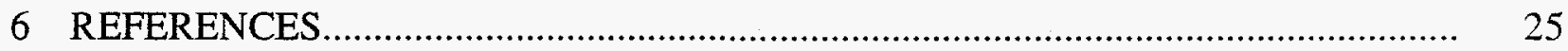




\section{FIGURES}

1 Relative Space Heating Share Values: Low Discount Rate Case

2 Relative Space Heating Share Values: High Discount Rate Case ....

3 Relative Space Heating Share Values: High vs. Low Discount Rate Case

\section{TABLES}

1 Parameter Estimates for Space Heating Share Equations

2 Parameter Estimates for Water Heating Share Equations.

3 Parameter Estimates for Cooking Share Equations

41990 Actual and Estimated Space Heating Shares by Income Category

51990 Actual and Estimated Water Heating Shares by Income Category

61987 Actual and Estimated Space Heating Shares by Income Category

71987 Actual and Estimated Water Heating Shares by Income Category 


\section{ACKNOWLEDGMENTS}

The authors of this report thank the U.S. Department of Energy (DOE) Office of Economic Impact and Diversity (ED) for its support. The authors extend specific thanks to Georgia Johnson, ED's Socioeconomic Research and Analysis Program Manager, and to John H. Cymbalsky (DOE), Energy Information Administration (EIA). 


\title{
THE DISTRIBUTIVE IMPACT ASSESSMENT MODEL (DIAM): TECHNOLOGY SHARE COMPONENT
}

by

\author{
D.A. Poyer, E. Earl, and B. Bonner
}

\begin{abstract}
The models described in this report are used to allocate total energy consumption in an energy end-use service area by fuel type (including electricity) within the Distributive Impact Assessment Model (DIAM) framework. The primary objective of the DIAM is to provide energy consumption and expenditure forecasts for different population categories that are consistent with the U.S. Department of Energy (DOE) Energy Information Administration's (EIA's) National Energy Modeling System (NEMS) forecast, which is produced annually in the Annual Energy Outlook and periodically in support of DOE policy formulation and analysis. The models are multinominal logit models that have been estimated using EIA's 1990 Residential Energy Consumption Survey. Three models were estimated: space heating share, water heating share, and cooking share. These models are used to allocate total end-use service consumption over different technologies defined by fuel type characteristics. For each of the end-use service categories, consumption shares are estimated for a subset of six fuel types: natural gas, electricity, liquid petroleum gas, fuel oil/kerosene, wood, and other fuel.
\end{abstract}

\section{INTRODUCTION}

In order for the Distributive Impact Assessment Model (DIAM) to be more consistent with the U.S. Department of Energy (DOE) Energy Information Administration's (EIA's) National Energy Modeling System (NEMS) technology choice methodology, DIAM now includes technology choice models. These models are used to calculate end-use technology market shares. Like the NEMS technology choice models, ${ }^{1}$ these share models are dependent on life-cycle costs and "consumer bias." The DIAM share model also includes other variables that capture the effect of a few select demographic and household variables, as well as weather variables.

\footnotetext{
${ }^{1}$ For a description of the residential component of NEMS, see DOE (1994).
} 
DIAM collapses the seven service areas modeled in NEMS into five service areas:

- Space heating,

- Electric central air conditioning,

- Water heating,

- Cooking, and

- Electric base load.

The technological shares within these service areas are defined only by fuel type, whereas in the NEMS residential model they are more specifically defined. Fuel-switching is considered only in the space heating, water heating, and cooking end-use service areas. It is assumed not to occur in the central air conditioning and base load service areas, where electricity is assumed to be the only energy source.

The share model is a logit specification (Maddala 1983; Judge et al. 1985). The logitshare equations are a function of indices, which in turn are dependent on variables that differentially affect the odds of choosing one system over another. The index is linear in form:

$$
f_{j}\left(I c_{j}, O c_{j}, x_{j}\right)=-\left(I c_{j}+\frac{O c_{j}}{r}\right)+\beta_{j} x_{j}
$$

where

$$
\begin{aligned}
I c_{j} & =\text { installation cost for alternative } j \\
O c_{j} & =\text { operating cost for alternative } j \\
r & =\text { consumer discount rate } \\
\beta_{j} & =\text { vector of coefficients associated with alternative } j ; \text { and } \\
x_{j} & =\text { vector of explanatory variables associated with alternative } j .
\end{aligned}
$$


The life-cycle cost of alternative $j$ is the expression shown in parentheses. ${ }^{2}$ The estimate of the probability, $P r$, of a household choosing alternative $j$ is

$$
\operatorname{Pr}\left(y_{j}=1\right)=\frac{e^{f_{j}\left(c_{j}, o c_{j}, x_{j}\right)}}{1+\sum_{i=1}^{n} e^{f_{i}\left(c_{i}, o c_{i}, x_{i}\right)}},
$$

where $y_{j}$ is a binomial variable that is equal to 1 if alternative $j$ is chosen and 0 otherwise.

In the case of the space heating end-use service category, there are six fuel-type options:

- Natural gas,

- Electricity,

- Liquid petroleum gas (LPG),

- Fuel oil and kerosene,

- Wood, and

- Other fuel.

${ }^{2}$ It is assumed that the influence of the system costs is captured in the estimate of the constant term and that the consumer discount rate can be derived from the installation and operating cost coefficients. Mathematically, the argument is:

$$
\begin{aligned}
& f_{j}\left(I c_{j}, O c_{j}, x_{j}\right)=\beta_{j 0}+\sum_{i=1}^{n} \beta_{j i} x_{j i} \\
& \beta_{0}=\left[\beta_{0}+\left(\alpha I c_{j 0}+\gamma O c_{j 0}\right)\right]-\left(\alpha I c_{j 0}+\gamma O c_{j 0}\right)
\end{aligned}
$$

The consumer discount rate can be empirically derived from estimates of $\alpha$ and $\gamma$ by dividing the former by the latter. Therefore, the implied discount rate is

$$
r=\frac{\alpha}{\gamma}
$$

In this model, an assumed discount rate is used. Installation and operating costs are set equal to 1 in the base period. The effect of changing operating and installation costs on technology shares in subsequent periods is determined by applying fuel-specific installation and operating cost growth rates. 
For the water heating end-use service area, there are five fuel-type options:

- Natural gas,

- Electricity,

- LPG,

- Fuel oil and kerosene, and

- Other fuel.

For the cooking end-use service area, there are four fuel-type options:

- Natural gas,

- Electricity,

- LPG, and

- Other fuel.

In order to estimate the system of share equations and ensure that the resulting probabilities sum to 1 , the set of coefficients associated with the natural gas index were set equal to 0 . The parameter estimates are listed in Tables 1-3.

Because of the normalization rule, an estimated parameter measures the probability difference of selecting one fuel with respect to natural gas. Over time, change in a fuel's market share is a function of changes in installation and operating costs and in the composition of other variables specified in the model. Later, the simulated effect of lower electricity installation costs on space heating shares will be presented as an example.

Since installation and operating costs are not reported in the EIA's Residential Energy Consumption Survey (RECS) data files, the effect of life-cycle costs on shares cannot be estimated. Neither an estimate of the discount rate nor the degree of its statistical significance is known. It is assumed that the effect of life-cycle cost on share value is embodied in the constant term (Footnote 2). With this assumption, along with the normalization of operating and installation costs in the base period, ${ }^{3}$ the influence of life-cycle costs on appliance shares can be simulated.

For each fuel type/end use, changes in fuel-specific operating and installation costs will be determined by weighting the fuel-/technology-type option by its share of the market in that fuel-type/end-use segment. For example, if the fuel-type and end-use category for natural gas

${ }^{3}$ In the base period, operating and installation costs are set equal to 1 . 
TABLE 1 Parameter Estimates for Space Heating Share Equations ${ }^{a}$

\begin{tabular}{|c|c|c|c|c|c|}
\hline Variable Name & $\begin{array}{c}\text { Liquid } \\
\text { Petroleum } \\
\text { Gas } \\
\end{array}$ & $\begin{array}{l}\text { Fuel Oil/ } \\
\text { Kerosene } \\
\end{array}$ & Wood & Other Fuel & Electricity \\
\hline Constant & $\begin{array}{l}-2.9421 \\
(0.4771)\end{array}$ & $\begin{array}{l}-0.5605 \\
(0.2489)\end{array}$ & $\begin{array}{l}-0.9012 \\
(0.4327)\end{array}$ & $\begin{array}{l}-1.4939 \\
(0.9362)\end{array}$ & $\begin{array}{l}-0.1303 \\
(0.2173)\end{array}$ \\
\hline $\begin{array}{l}\text { Cooling-Degree Days } \\
\left(65^{\circ} \mathrm{F} \text { base }\right)\end{array}$ & $\begin{array}{c}4.5010 \times 10^{-4} \\
\left(1.3926 \times 10^{-4}\right)\end{array}$ & $\begin{array}{c}-9.0107 \times 10^{-4} \\
\left(1.0261 \times 10^{-4}\right)\end{array}$ & $\begin{array}{l}-9.5700 \times 10^{-4} \\
\left(1.6839 \times 10^{-4}\right)\end{array}$ & $\begin{array}{c}4.5677 \times 10^{-4} \\
\left(2.1474 \times 10^{-4}\right)\end{array}$ & $\begin{array}{r}2.5428 \times 10^{-4} \\
\left(5.8693 \times 10^{-5}\right)\end{array}$ \\
\hline $\begin{array}{l}\text { Heating-Degree Days } \\
\left(65^{\circ} \mathrm{F} \text { base }\right)\end{array}$ & $\begin{array}{c}9.2169 \times 10^{-5} \\
\left(6.4941 \times 10^{-5}\right)\end{array}$ & $\begin{array}{r}7.0298 \times 10^{-6} \\
\left(3.3369 \times 10^{-5}\right)\end{array}$ & $\begin{array}{l}-1.7304 \times 10^{-4} \\
\left(5.9115 \times 10^{-5}\right)\end{array}$ & $\begin{array}{c}-5.2970 \times 10^{-4} \\
\left(1.4629 \times 10^{-4}\right)\end{array}$ & $\begin{array}{l}-1.7023 \times 10^{-4} \\
\left(3.3263 \times 10^{-5}\right)\end{array}$ \\
\hline Heated Area $\left(\mathrm{ft}^{2}\right)$ & $\begin{array}{l}-1.7315 \times 10^{-4} \\
\left(9.0646 \times 10^{-5}\right)\end{array}$ & $\begin{array}{c}1.1918 \times 10^{-4} \\
\left(4.2032 \times 10^{-5}\right)\end{array}$ & $\begin{array}{c}6.1496 \times 10^{-5} \\
\left(7.0390 \times 10^{-5}\right)\end{array}$ & $\begin{array}{l}-2.2122 \times 10^{-3} \\
\left(2.7452 \times 10^{-4}\right)\end{array}$ & $\begin{array}{l}-3.9016 \times 10^{-4} \\
\left(5.5995 \times 10^{-5}\right)\end{array}$ \\
\hline Central City & $\begin{array}{l}-2.3407 \\
(0.3498)\end{array}$ & $\begin{array}{l}-0.5958 \\
(0.1013)\end{array}$ & $\begin{array}{l}-1.6514 \\
(0.3070)\end{array}$ & $\begin{array}{l}-1.2876 \\
(0.5080)\end{array}$ & $\begin{array}{c}-0.3253 \\
\left(9.2636 \times 10^{-2}\right)\end{array}$ \\
\hline Nonmetropolitan & $\begin{array}{c}1.2088 \\
(0.1549)\end{array}$ & $\begin{array}{l}9.7958 \times 10^{-2} \\
(0.1135)\end{array}$ & $\begin{array}{c}1.4338 \\
(0.1629)\end{array}$ & $\begin{array}{c}2.0210 \\
(0.3316)\end{array}$ & $\begin{array}{c}0.1349 \\
(0.1070)\end{array}$ \\
\hline Household Income & $\begin{array}{c}-1.2289 \times 10^{-5} \\
\left(3.0880 \times 10^{-5}\right)\end{array}$ & $\begin{array}{l}-1.6772 \times 10^{-6} \\
\left(1.0166 \times 10^{-6}\right)\end{array}$ & $\begin{array}{c}-6.6074 \times 10^{-6} \\
\left(3.2563 \times 10^{-6}\right)\end{array}$ & $\begin{array}{c}7.0261 \times 10^{-6} \\
\left(2.5190 \times 10^{-6}\right)\end{array}$ & $\begin{array}{c}3.3287 \times 10^{-7} \\
\left(1.1367 \times 10^{-6}\right)\end{array}$ \\
\hline Black & $\begin{array}{l}-0.4328 \\
(0.2701)\end{array}$ & $\begin{array}{c}9.5173 \times 10^{-2} \\
(0.1529)\end{array}$ & $\begin{array}{l}-1.4365 \\
(0.5118)\end{array}$ & $\begin{array}{l}-2.4976 \\
(0.9457)\end{array}$ & $\begin{array}{l}-0.5519 \\
(0.1350)\end{array}$ \\
\hline Latino & $\begin{array}{l}-1.3970 \\
(0.5120)\end{array}$ & $\begin{array}{l}-0.1601 \\
(0.2119)\end{array}$ & $\begin{array}{l}-0.3177 \\
(0.4015)\end{array}$ & $\begin{array}{c}-9.8216 \times 10^{-2} \\
(0.4587)\end{array}$ & $\begin{array}{l}-0.4055 \\
(0.1427)\end{array}$ \\
\hline
\end{tabular}

${ }^{a}$ Parentheses indicate standard error terms; log-likelihood ratio $=1535.443$. 
TABLE 2 Parameter Estimates for Water Heating Share Equations ${ }^{\text {a }}$

\begin{tabular}{|c|c|c|c|c|}
\hline Variable Name & $\begin{array}{c}\text { Liquid } \\
\text { Petroleum } \\
\text { Gas } \\
\end{array}$ & $\begin{array}{l}\text { Fuel Oil/ } \\
\text { Kerosene } \\
\end{array}$ & Other Fuel & Electricity \\
\hline Constant & $\begin{array}{l}-4.5790 \\
(0.5048)\end{array}$ & $\begin{array}{l}-1.6358 \\
(0.3241)\end{array}$ & $\begin{array}{l}-2.9830 \\
(0.7704)\end{array}$ & $\begin{array}{l}-0.5386 \\
(0.1807)\end{array}$ \\
\hline $\begin{array}{l}\text { Cooling-Degree Days } \\
\left(65^{\circ} \mathrm{F} \text { base }\right)\end{array}$ & $\begin{array}{c}7.6854 \times 10^{-4} \\
\left(1.4346 \times 10^{-4}\right)\end{array}$ & $\begin{array}{c}-8.6293 \times 10^{-4} \\
\left(1.4564 \times 10^{-4}\right)\end{array}$ & $\begin{array}{c}2.7788 \times 10^{-4} \\
\left(2.0373 \times 10^{-4}\right)\end{array}$ & $\begin{array}{r}2.5874 \times 10^{-4} \\
\left(5.3053 \times 10^{-5}\right)\end{array}$ \\
\hline $\begin{array}{l}\text { Heating-Degree Days } \\
\left(65^{\circ} \mathrm{F} \text { base }\right)\end{array}$ & $\begin{array}{c}2.6968 \times 10^{-4} \\
\left(6.7713 \times 10^{-5}\right)\end{array}$ & $\begin{array}{r}7.8831 \times 10^{-5} \\
\left(4.5364 \times 10^{-5}\right)\end{array}$ & $\begin{array}{l}-2.6427 \times 10^{-4} \\
\left(1.1893 \times 10^{-4}\right)\end{array}$ & $\begin{array}{c}-3.6218 \times 10^{-6} \\
\left(2.5773 \times 10^{-5}\right)\end{array}$ \\
\hline Heated Area $\left(\mathrm{ft}^{2}\right)$ & $\begin{array}{r}9.1186 \times 10^{-5} \\
\left(9.2234 \times 10^{-5}\right)\end{array}$ & $\begin{array}{c}1.0273 \times 10^{-4} \\
\left(5.8979 \times 10^{-5}\right)\end{array}$ & $\begin{array}{c}-5.3188 \times 10^{-4} \\
\left(1.7102 \times 10^{-4}\right)\end{array}$ & $\begin{array}{c}-1.8701 \times 10^{-4} \\
\left(3.6840 \times 10^{-5}\right)\end{array}$ \\
\hline Central City & $\begin{array}{l}-2.5638 \\
(0.4109)\end{array}$ & $\begin{array}{l}-0.5962 \\
(0.1435)\end{array}$ & $\begin{array}{c}-0.4602 \\
(0.3917)\end{array}$ & $\begin{array}{c}-0.4830 \\
\left(7.7361 \times 10^{-2}\right)\end{array}$ \\
\hline Nonmetropolitan & $\begin{array}{c}1.3071 \\
(0.1645)\end{array}$ & $\begin{array}{c}-0.8121 \\
(0.1922)\end{array}$ & $\begin{array}{c}1.2840 \\
(0.3352)\end{array}$ & $\begin{array}{c}1.0074 \\
\left(7.9235 \times 10^{-2}\right)\end{array}$ \\
\hline Household Income & $\begin{array}{c}5.1028 \times 10^{-6} \\
\left(3.3416 \times 10^{-6}\right)\end{array}$ & $\begin{array}{r}1.3176 \times 10^{-7} \\
\left(1.1897 \times 10^{-6}\right)\end{array}$ & $\begin{array}{c}3.8545 \times 10^{-6} \\
\left(2.1153 \times 10^{-6}\right)\end{array}$ & $\begin{array}{l}-9.8474 \times 10^{-7} \\
\left(1.0552 \times 10^{-6}\right)\end{array}$ \\
\hline Black & $\begin{array}{l}-0.2280 \\
(0.2933)\end{array}$ & $\begin{array}{c}0.3429 \\
(0.2142)\end{array}$ & $\begin{array}{l}-1.4939 \\
(0.7110)\end{array}$ & $\begin{array}{l}-0.4192 \\
(0.1113)\end{array}$ \\
\hline Latino & $\begin{array}{l}-1.1017 \\
(0.4490)\end{array}$ & $\begin{array}{c}9.9730 \times 10^{-2} \\
(0.2493)\end{array}$ & $\begin{array}{l}-1.2286 \\
(0.7320)\end{array}$ & $\begin{array}{l}-0.7372 \\
(0.1436)\end{array}$ \\
\hline
\end{tabular}

a Parentheses indicate standard error terms; log-likelihood ratio $=884.5048$. 
TABLE 3 Parameter Estimates for Cooking Share Equations ${ }^{\text {a }}$

\begin{tabular}{|c|c|c|c|}
\hline Variable Name & $\begin{array}{l}\text { Liquid } \\
\text { Petroleum } \\
\text { Gas }\end{array}$ & Other Fuel & Electricity \\
\hline Constant & $\begin{array}{l}-2.9699 \\
(0.4108)\end{array}$ & $\begin{array}{l}-1.6391 \\
(1.5635)\end{array}$ & $\begin{array}{l}-0.4889 \\
(0.1683)\end{array}$ \\
\hline $\begin{array}{l}\text { Cooling-Degree Days } \\
\left(65^{\circ} \mathrm{F} \text { base }\right)\end{array}$ & $\begin{array}{c}7.0058 \times 10^{-4} \\
\left(1.1708 \times 10^{-4}\right)\end{array}$ & $\begin{array}{c}1.0681 \times 10^{-3} \\
\left(7.3728 \times 10^{-4}\right)\end{array}$ & $\begin{array}{r}4.4145 \times 10^{-4} \\
\left(4.9787 \times 10^{-5}\right)\end{array}$ \\
\hline $\begin{array}{l}\text { Heating-Degree Days } \\
\left(65^{\circ} \mathrm{F} \text { base }\right)\end{array}$ & $\begin{array}{c}2.6171 \times 10^{-4} \\
\left(5.6474 \times 10^{-5}\right)\end{array}$ & $\begin{array}{c}3.0034 \times 10^{-4} \\
\left(1.8824 \times 10^{-4}\right)\end{array}$ & $\begin{array}{c}1.5089 \times 10^{-4} \\
\left(2.4042 \times 10^{-5}\right)\end{array}$ \\
\hline Heated Area $\left(\mathrm{ft}^{2}\right)$ & $\begin{array}{c}-4.0071 \times 10^{-4} \\
\left(8.7688 \times 10^{-5}\right)\end{array}$ & $\begin{array}{c}-4.5299 \times 10^{-3} \\
\left(1.1977 \times 10^{-3}\right)\end{array}$ & $\begin{array}{c}5.0650 \times 10^{-5} \\
\left(3.3773 \times 10^{-5}\right)\end{array}$ \\
\hline Central City & $\begin{array}{l}-2.1702 \\
(0.2719)\end{array}$ & $\begin{array}{c}4.2264 \times 10^{-2} \\
(0.8048)\end{array}$ & $\begin{array}{c}-0.5729 \\
\left(6.9800 \times 10^{-2}\right)\end{array}$ \\
\hline Nonmetropolitan & $\begin{array}{c}1.2250 \\
(0.1410)\end{array}$ & $\begin{array}{c}1.1955 \\
(0.8784)\end{array}$ & $\begin{array}{c}0.3879 \\
(0.0815)\end{array}$ \\
\hline Household Income & $\begin{array}{l}-5.0522 \times 10^{-6} \\
\left(3.0751 \times 10^{-6}\right)\end{array}$ & $\begin{array}{l}-3.0006 \times 10^{-5} \\
\left(2.9481 \times 10^{-5}\right)\end{array}$ & $\begin{array}{r}1.6145 \times 10^{-6} \\
\left(9.1779 \times 10^{-7}\right)\end{array}$ \\
\hline Black & $\begin{array}{l}-0.6166 \\
(0.2152)\end{array}$ & $\begin{array}{c}-0.2614 \\
(1.0225)\end{array}$ & $\begin{array}{c}-1.0106 \\
\left(9.9626 \times 10^{-2}\right)\end{array}$ \\
\hline Latino & $\begin{array}{l}-1.3511 \\
(0.3413)\end{array}$ & $\begin{array}{c}0.7409 \\
(0.8727)\end{array}$ & $\begin{array}{l}-0.9599 \\
(0.1208)\end{array}$ \\
\hline
\end{tabular}

${ }^{a}$ Parentheses indicate standard error terms; $\log$-likelihood ratio $=773.6882$. 
space heating were composed of $5 \%$ natural gas heat pumps and $90 \%$ other natural gas, the operating and installation costs associated with natural gas heat pumps and other natural gas systems would be weighted by a factor of 0.05 and 0.95 , respectively. Summing these weighted values yields an estimate of operating and installation costs for natural gas space heating systems. These estimates are then used to calculate changes in operating and installation costs.

The 1990 Residential Energy Consumption Survey (RECS6) data and the SHAZAM Econometrics computer program's nonlinear estimation procedure were used to estimate the multinominal logit share models (DOE 1993; SHAZAM 1993). 


\section{SPACE HEATING SHARE MODEL}

The parameter estimates give a measure of how a variable affects the odds ratio of a particular fuel (or electricity) with respect to natural gas. The estimated equation for each of the space heating technologies is described separately. Where possible, inferences from the parameter estimates are given.

In all cases the estimated constant term is negative, indicating that the net effect of all excluded variables increases the probability of using natural gas relative to the other alternatives. Other variables that have the same qualitative effect on the odds ratio for each of the five technologies are the metropolitan location variables - central city and nonmetropolitan location - and Latino ethnicity.

Metropolitan location plays an important role in determining the type of fuel used for space heating. For each of the space heating alternatives, the central city variable is negative and statistically significant, whereas nonmetropolitan location is positive in each case and highly significant in the LPG, wood, and other-fuel cases.

It is asserted that metropolitan location variables pick up the influence that population density has on natural gas distribution cost. It is presumed that in more densely populated areas, the distribution costs of natural or piped gas are typically lower. Therefore, it is proposed that natural gas space heating share will rise in central cities and fall in nonmetropolitan areas, as indicated by the equation parameter estimates.

The Latino variable is negatively related to each of the estimated technologies but is only marginally significant in the LPG and electricity equations.

\subsection{LIQUID PETROLEUM GAS}

The absolute value of the estimated constant term is largest in the LPG equation. This implies that the net effect of excluded variables on space heating share is largest in the LPG equation, with the collective effect of these unobserved factors on LPG space heating share being very negative.

Along with the constant term, the metropolitan location variables are highly important. The probability of having an LPG-based space heating system in a central city location is very small. The probability dramatically increases in nonmetropolitan areas. The magnitude and level of statistical significance of both metropolitan location variables are large. The magnitude of the absolute effect of central city location is greatest in the LPG equation.

The household income variable is statistically most significant in the LPG space heating share equation, and its effect on space heating share is negative - the higher the income, the smaller the estimated LPG space heating share. 
The parameter estimates indicate that LPG is more likely to be used for space heating by low-income non-Latino whites living in the rural South.

\subsection{FUEL OIL AND KEROSENE}

In the fuel oil and kerosene share equation, the cooling-degree day variable is important. It is negatively related to the estimated space heating share of fuel oil/kerosene and is highly significant. Conversely, the estimated coefficient of the heating-degree day variable is statistically insignificant and positive.

Central city location is also important. The estimated probability of using fuel oil/kerosene for space heating falls in central city locations. Fuel oil and kerosene are more likely to be used for space heating in larger homes located in suburban northern areas.

\subsection{WOOD}

Metropolitan location and weather are important factors influencing the use of wood for space heating. Both metropolitan location variables - central city and nonmetropolitan location - are statistically significant. The central city location variable is negatively related to the estimated space heating share value of wood, whereas nonmetropolitan location is positively related.

Both cooling- and heating-degree days are negatively related to the wood space heating share estimate and are statistically significant. The negativity of both estimates implies that there is some optimal trade-off between cooling- and heating-degree days. Given that the marginal and negative effect of cooling-degree days is much larger, this suggests that the use of wood for space heating will occur most frequently in areas with low to moderate cooling loads. The parameter estimates indicate that wood is more likely to be used for space heating by white households living in homes located in rural northern areas.

\subsection{ELECTRICITY}

Many factors influence electricity use: weather, metropolitan location, size of home, ethnicity, and race. Also, it is worth noting that the net effect of excluded factors, as measured by the constant term, is statistically insignificant in the electricity equation.

The effect of weather on the electric and other-fuel space heating shares is similar. The estimated electric space heating share rises with cooling-degree days and falls with heatingdegree days. 
The size of the home's heated area and the estimated space heating share are negatively related for electric space heating technologies. Therefore, use of electricity for space heating is more likely to occur in smaller homes.

Electricity is less likely to be used for space heating in central cities. However, the relative magnitude of the effect of central city location on electric space heating share is small compared to the other options. Therefore, the absolute effect that central city location has on the electric and natural gas space heating odds ratio is smaller than for other space heating system options.

Nonmetropolitan location is statistically insignificant in the electricity equation, as it was in the case of fuel oil and kerosene. This empirical result, along with that associated with central city location, indicates that electricity use for space heating is more frequent in suburban areas relative to natural gas.

Both race and Latin ethnicity are statistically significant. The estimates indicate that black and Latin households are less likely to use electricity for space heating relative to natural gas.

In relationship to natural gas, the parameter estimates indicate that electricity is more likely to be used for space heating by non-Latino whites living in small homes (possibly townhouses, mobile homes, or apartments) located in suburban southern and western areas.

\subsection{OTHER FUEL}

The other-fuel category is an amalgam of coal or coke, solar collectors, no fuel used, and miscellaneous. A wide variety of factors significantly influence the likelihood of using other fuels for space heating - weather, area heated within the home, metropolitan location, household income,.and race of the household head.

Both cooling- and heating-degree days are marginally significant. Cooling-degree days are positively related to the estimated probability of using other fuels for space heating, and heating-degree days are negatively related. The signs of the cooling- and heating-degree-day parameters imply that the space heating share for other fuels is largest in very warm areas with very low heating loads.

The area-heated variable is more significant in the other-fuel equation than it is in any other space heating equation. The variable is highly significant and is negatively related to other fuel's estimated space heating share, thus suggesting that other fuels are more often used in smaller homes.

As in many other cases, metropolitan location is a factor in determining space heating share. Both central city and nonmetropolitan location are statistically significant. Central city location and space heating share are negatively related, while nonmetropolitan location and 
share are positively related. From these results, the estimated space heating share for other fuels will rise in nonmetropolitan areas.

In the other-fuel equation, household income is marginally significant and is positively related to the estimate of other-fuel share. Only in the other-fuel equation is household income both statistically significant and positive.

In relationship to natural gas, the parameter estimates indicate that other fuels are more likely to be used for space heating by moderate-income white households living in small homes (possibly mobile or small summer homes) located in rural southern and western areas. 


\section{WATER HEATING SHARE MODEL}

Like the parameter estimates for the space heating share equation, the parameter estimates for the water heating share equations give a measure of how a variable affects the odds ratio of a particular fuel (or electricity) with respect to natural gas. As in the case of the space heating share model, all of the estimated constant terms are negative, again indicating that the net effect of all excluded variables increases the probability of using natural gas relative to the other alternatives.

Central city location is the only variable that has, in relationship to natural gas, the same qualitative effect on the odds ratio for each of the four water heating technologies. For each of the technologies, the estimated water heating share falls, relative to natural gas, in the central city location when other variables are held constant.

Again, it is asserted that the metropolitan location variables pick up the influence that population density has on natural gas distribution cost and that the share of natural gas systems will rise in central cities and fall in nonmetropolitan areas because of the respective fall and rise of natural gas distribution costs in these areas.

\subsection{LIQUID PETROLEUM GAS}

As in the case of the space heating share model, the absolute value of the estimated constant term is largest in the LPG equation, implying that the net effect of excluded variables on water heating share is largest in the LPG equation. Again, the collective effect of these unobserved factors on LPG space heating share is very negative.

The estimated LPG water heating share is highly dependent on weather and metropolitan location variables. The qualitative effects of these variables on LPG water heating share are the same as in the space heating share model.

Both the cooling- and heating-degree-day variables have the same sign and are statistically significant. The magnitude of the effect of cooling-degree days on LPG water heating share is greater than that of heating-degree days. As mentioned earlier, under these circumstances, the LPG share will increase with rising cooling-degree days.

In the LPG equation, the magnitude and level of statistical significance of both metropolitan location variables are large. The magnitude of the effect of central city and nonmetropolitan location is greatest in the LPG equation. As in the space heating model, central city location is negatively related to LPG water heating share, and nonmetropolitan location is positively related.

The parameter estimates indicate that LPG is more likely to be used for water heating by non-Latinos living in the rural South. 


\subsection{FUEL OIL AND KEROSENE}

In the fuel oil and kerosene share equation, the cooling-degree-day variable is once again important. As in the space heating share model, it is negatively related to the estimated water heating share of fuel oil/kerosene and is statistically significant. Both central city and nonmetropolitan location variables are significant in the fuel oil and kerosene equation. The estimated fuel oil and kerosene water heating share falls in both locations, indicating that the share of fuel oil and kerosene relative to natural gas increases in metropolitan suburbs. Fuel oil and kerosene are more likely to be used for water heating in homes located in suburban northern areas.

\subsection{ELECTRICITY}

In the electricity equation, each of the specified variables, except for heating-degree days, is statistically significant. The net effect of excluded variables on electricity use for water heating is negative and statistically significant; however, its absolute magnitude in the electric share equation is smaller than that for other share equations.

In the case of electric water heating, the cooling-degree day variable and the estimated electric water heating share are positive and statistically significant. Unlike the situation found in the space heating model, the heating-degree-day variable is not statistically significant; however, it does have the same negative sign.

Once again, the size of the home's heated area is related to the estimated space heating share. As in the space heating case, the estimated water heating share for electricity and the area heated are negatively related.

Both metropolitan location variables are statistically significant in the electric water heating share equation. The relationship between nonmetropolitan location and electric water heating share is particularly strong. Central city location is negatively related to electric water heating share, and nonmetropolitan location is positively related.

Again, both race and Latin ethnicity are statistically significant. As in the space heating model, the estimates indicate that black and Latin households are less likely to use electricity, relative to natural gas, for space heating.

The parameter estimates indicate that electricity is more likely to be used for water heating by non-Latino whites living in small homes (possibly mobile homes, townhouses, or apartments) located in southern and western suburban and nonmetropolitan areas.

\subsection{OTHER FUEL}

In the case of water heating, the other-fuel category includes coal and coke, wood, solar collectors, and other miscellaneous systems. The net effect of excluded variables on the water 
heating share of other-fuel systems is significant. The magnitude of the effect is only greater in the case of LPG.

Heated-area and nonmetropolitan location are also statistically significant. The estimated coefficient for area heated in the other-fuel equation is negative, therefore suggesting that other-fuel systems are less likely in larger homes. For the other-fuel water heating equation, nonmetropolitan location is statistically significant and positively related to the other-fuel water heating share.

In relationship to natural gas, the parameter estimates indicate that other-fuel water heating is more likely in small homes located in rural areas. 


\section{COOKING SHARE MODEL}

The cooking end-use service category contains four options: natural gas, LPG, electricity, and other fuels. The other-fuel category includes fuel oil, kerosene or coal oil, coal or coke, wood, other miscellaneous, and no cooking.

As in the case of the other end-use service share models, all of the estimated constant terms are negative, again indicating that the net effect of the excluded variables increases the probability of using natural gas relative to the other alternatives. However, the estimated constant term for the other-fuel system equation is statistically insignificant.

The weather variables have the same qualitative effect on the odds ratio. For each of the technologies, the estimated cooking share rises with cooling- and heating-degree days relative to natural gas when holding other variables constant. This result is difficult to explain; there is neither a technical nor a theoretical reason that readily accounts for the relationship between cooling- and heating-degree days and cooking shares. It is likely that these variables are substitutes for other factors that influence cooking-fuel choices, such as regional location, which is correlated to fuel price, and other appliance choices, which are dependent on weather.

\subsection{LIQUID PETROLEUM GAS}

As in the case of the other share models, the absolute value of the estimated constant term is largest in the LPG equation, suggesting that the net effect of excluded variables on cooking share is largest in the LPG equation. Again, the collective effect of these unobserved factors on LPG cooking share is very negative.

In the LPG equation, the parameter estimates are statistically significant. The estimated LPG cooking share is highly dependent on weather, home size, metropolitan location, and race and ethnicity variables.

Both cooling- and heating-degree-day values are significant and positive. The value of the cooling-degree-day coefficient is larger. However, the positive signs of the degree-day variables suggest that the full increase implied by the coefficients will not occur. Some of the increase will be offset by a decline in the contribution of the other degree-day variable, which is denoted by a negative relationship between cooling- and heating-degree days.

In the LPG cooking share equation, the area-heated coefficient is also statistically significant. Since LPG is used extensively in mobile homes, the negative sign probably reflects this fact.

In the LPG equation, again the magnitude and level of statistical significance of both metropolitan location variables are large. As in the water heating model, the magnitude of the effect of central city and nonmetropolitan location is greatest in the LPG equation. As in each 
of the other models, central city location is negatively related to LPG water heating share, and nonmetropolitan location is positively related.

The parameter estimates indicate that LPG is more likely to be used for cooking by nonLatino whites living in small homes in the rural South.

\subsection{ELECTRICITY}

Again in the electricity equation, most of the specified variables are statistically significant. The net effect of excluded variables on electricity use for water heating is negative and statistically significant. However, the absolute magnitude of the electric cooking share, as in the case of the water heating model, is smaller than that for the other share equations.

There is a positive relationship between the cooling- and heating-degree-day variables and the estimated electric cooking share. The cooling- and heating-degree-day variables are both statistically significant. Given their relative size, the likelihood of electric cooking is greater in the South.

Both location variables are statistically significant in the electric cooking share equation. The relationship between central city location and electric-cooking share is especially strong. As in the other two models, central city location and electric-cooking share are negatively related, whereas nonmetropolitan location and electricity share are positively related.

In the electricity equations, race and Latino ethnicity have been statistically significant, and as in every other case, the relationship is negative. In relation to natural gas, the parameter estimates indicate that electricity is more likely to be used for cooking in non-Latino white households located in suburban southern and nonmetropolitan areas.

\subsection{OTHER FUEL}

In the case of cooking, the other-fuel category includes fuel oil, kerosene or coal oil, coal or coke, wood, no cooking, and other miscellaneous systems. In general, the variables in the other-fuel equation are not highly significant, indicating that the set of variables used to specify other systems does not effectively distinguish other fuels from natural gas cooking.

Heated area is the most significant variable in the other-fuel equation. The estimated coefficient for area heated in the other-fuel equation is negative, implying that other-fuel systems are less likely to be used in larger homes. In relation to natural gas, the parameter estimates indicate that other fuels are more likely to be used for cooking in smaller homes. 


\section{SENSITIVITY ANALYSIS}

Each of the models is very significant, with the log-likelihood ratio ranging from 774 for the cooking-share model to 1,535 for the space heating share model. Therefore, the "null" hypotheses suggesting that the specified model variables have no effect on the selection of technological alternatives are resoundingly rejected.

\subsection{LIFE-CYCLE COSTS}

One of the purposes of these share models is to capture the effect that changing life-cycle cost has on fuel appliance shares. The life-cycle cost is determined by the discount rate and the equipment's expected life. As mentioned earlier, the expected life of the three types of appliances is assumed to be infinite, and an assumed discount rate is used that is not statistically determined.

The value of the discount rate can be very important in determining shifts in relative market shares as operating costs change. The larger the discount rate, the more myopic is the household when making appliance investment decisions.

To demonstrate the potential sensitivity of the estimated technology end-use service shares to different discount rate assumptions, the effect of a fall in electricity operating cost on space heating shares is considered under two different discount rate scenarios - "low" and "high" rate cases. A discount rate of $100 \%$ is assumed in the low case and a rate of $10,000 \%$, in the high case. In the latter case, the household behaves myopically and, for all practical purposes, only considers installation costs in its appliance investment decision.

The results of the life-cycle cost sensitivity analysis are shown in Figures 1-3. The relative share for each of the technologies, with the exception of electricity, is the same for each of the cases. This implies that there is a similar shift in the relative technology share in each of the cases. For example, in Figure 2 (the low-electric-price/low-discount-rate case), the relative loss in share for each of the nonelectric technologies is the same. In the low-electric-price/lowdiscount-rate case, the price of electricity is assumed to decrease by half. As a result, the electricity share increases by about $47 \%$ when compared to the base case. In the high-electricprice/low-discount-rate case, the price of electricity is assumed to double. The electric share decreases by approximately $38 \%$ in this case. In contrast to these large shifts is the negligible change in relative technology shares for the high-discount-rate case, shown in Figure 2.

In Figure 3, relative changes in space heating share are shown for the low- and highdiscount-rate cases under the low-electric-price scenario. As expected, the relative increase in electric space heating share is substantially larger under the low-discount-rate case. Under this case, the electricity share increases by about 2.5 times over the base case. 

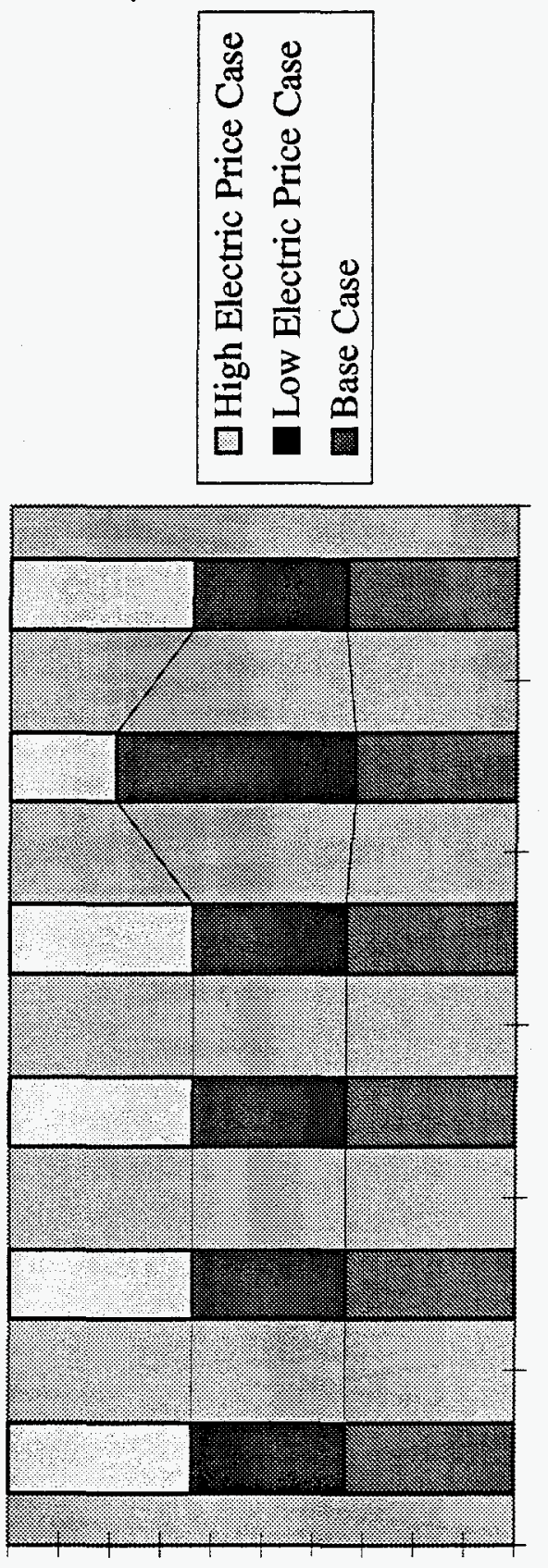

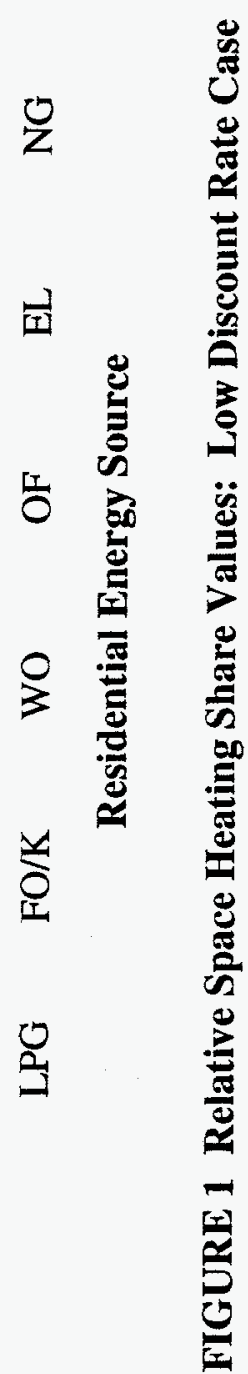

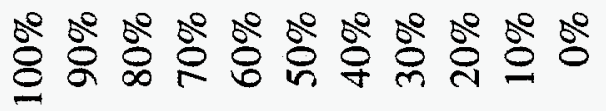

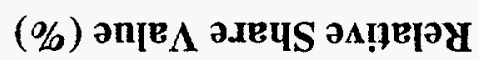




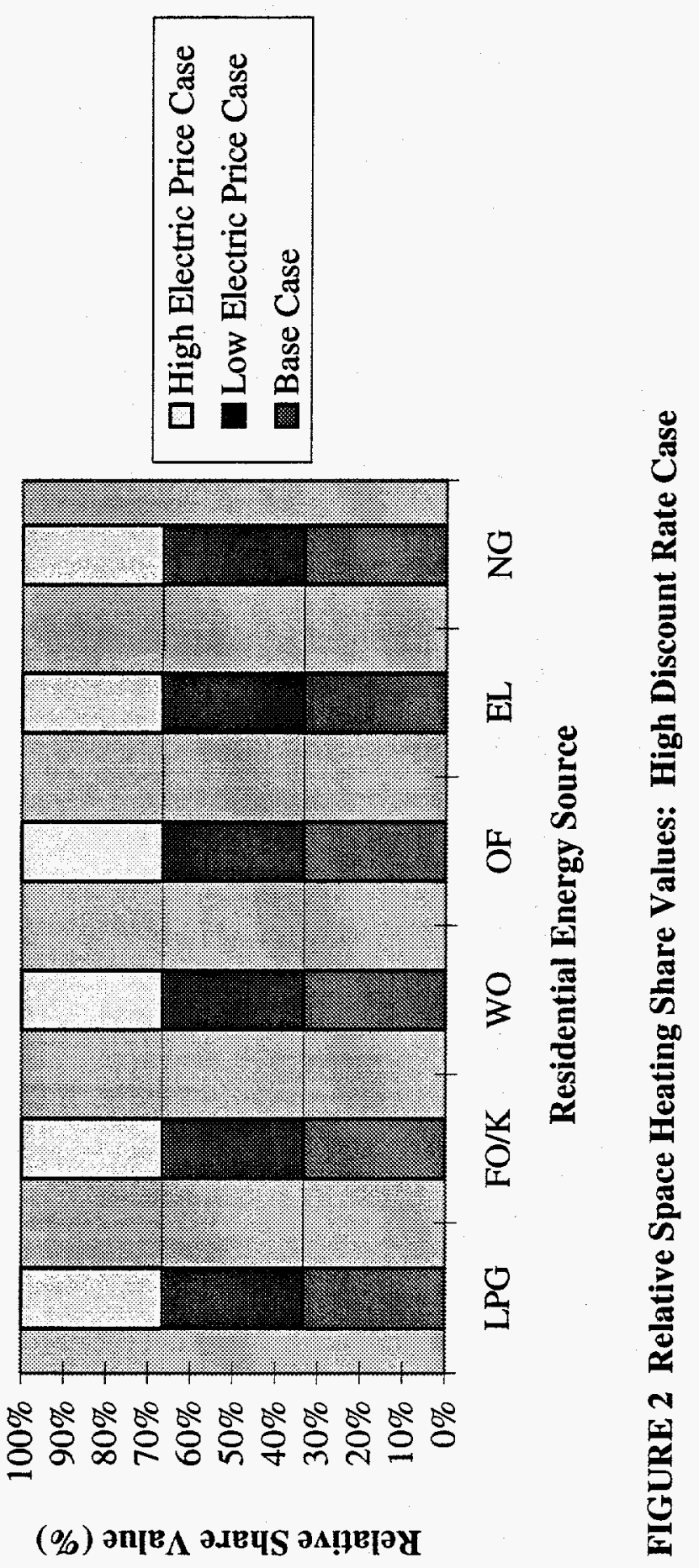




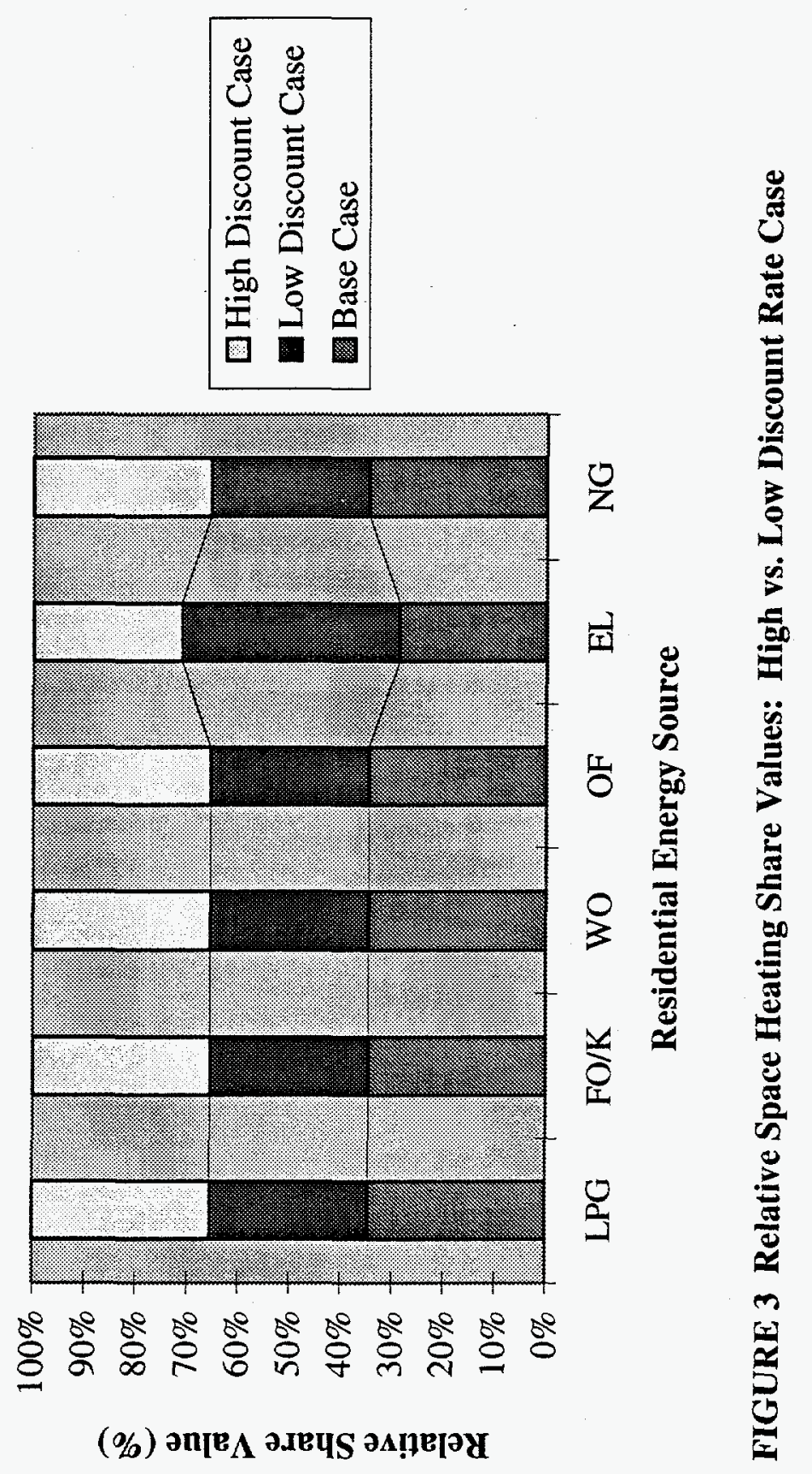




\subsection{INCOME QUINTILE SHARES}

It is important for the share model to provide good technology share estimates at the subgroup or disaggregated level, because the primary objective of the model is to provide a disaggregated breakdown of the distributive effects of energy policy on different population groups.

Tables 4 and 5 show comparisons by income quintile of the 1990 RECS sample means and the estimated sample means for natural gas and electricity space and water heating shares. For space heating, the percentage deviation from the actual ranges from -2.12 to $1.53 \%$ for natural gas and -6.57 to $4.16 \%$ for electricity. For water heating, the percentage deviation ranges from -2.88 to $3.05 \%$ for natural gas and -3.16 to $6.19 \%$ for electricity. As expected, the percentage deviations rise with those systems that account for a lower share of the end-use service market.

The actual and estimated variations in shares among the income quintile groups are not very large for either the space heating or the water heating end-use service areas. The relative rankings for the income quintiles by end-use service share are reasonably similar for the actual and estimated shares. The biggest discrepancy occurs in the water heating model. In the case of natural gas, Quintile Four's actual ranking is 1 , whereas its estimated ranking is 3 . In the case of electricity, Quintile Five's actual ranking is 3 but its estimated ranking is 1 . In all other cases, the actual and estimated rankings are never more than a place off.

\subsection{BACK-CASTING}

The individual share models were estimated by using the 1990 RECS sample. In order to get a better idea of how robust the model estimates are, the model was used to estimate shares against the 1987 RECS sample (DOE 1990). The results of this back-casting procedure are shown in Tables 6 and 7.

As expected, the percentage differences between the actual and estimated share values are larger. For the four cases - natural gas/space heating, natural gas/water heating, electricity/space heating, and electricity/water heating - an analysis of variance was conducted. In each case, the null hypothesis cannot be rejected at the 5\% level of significance. However, for the natural gas/space heating case, this condition is only marginally met. In the other three cases, the null hypothesis is strongly accepted. 
TABLE 41990 Actual and Estimated Space Heating Shares (percent) by Income Category

\begin{tabular}{lccccccc}
\hline & \multicolumn{3}{c}{ Natural Gas } & & \multicolumn{3}{c}{ Electricity } \\
\cline { 2 - 4 } \cline { 6 - 8 } Income Category & Actual & Estimated & $\begin{array}{c}\text { Percent } \\
\text { Deviation }\end{array}$ & & Actual & Estimated & $\begin{array}{c}\text { Percent } \\
\text { Deviation }\end{array}$ \\
\hline Quintile One & 58.34 & 58.64 & 0.50 & & 17.19 & 18.32 & 6.57 \\
Quintile Two & 57.60 & 57.50 & $(0.20)$ & & 19.70 & 18.88 & $(4.16)$ \\
Quintile Three & 56.59 & 57.79 & 2.12 & & 19.86 & 19.06 & $(4.03)$ \\
Quintile Four & 58.73 & 57.83 & $(1.53)$ & & 18.95 & 18.76 & $(1.00)$ \\
Quintile Five & 56.29 & 55.80 & $(0.87)$ & & 17.54 & 18.23 & 3.93 \\
\hline
\end{tabular}

Source: 1990 Residential Energy Consumption Survey (DOE 1993).

TABLE 51990 Actual and Estimated Water Heating Shares (percent) by Income Category

\begin{tabular}{lccccccc}
\hline & \multicolumn{3}{c}{ Natural Gas } & & \multicolumn{3}{c}{ Electricity } \\
\cline { 2 - 4 } \cline { 6 - 8 } Income Category & Actual & Estimated & $\begin{array}{c}\text { Percent } \\
\text { Deviation }\end{array}$ & & Actual & Estimated & $\begin{array}{c}\text { Percent } \\
\text { Deviation }\end{array}$ \\
\hline Quintile One & 57.03 & 56.66 & $(0.64)$ & & 32.36 & 32.79 & 1.33 \\
Quintile Two & 53.40 & 54.94 & 2.88 & & 36.50 & 34.24 & $(6.19)$ \\
Quintile Three & 55.43 & 55.42 & $(0.02)$ & & 34.20 & 33.88 & $(0.94)$ \\
Quintile Four & 57.14 & 55.40 & $(3.05)$ & & 32.84 & 33.86 & 3.11 \\
Quintile Five & 53.57 & 54.12 & 1.03 & & 33.58 & 34.64 & 3.16 \\
\hline
\end{tabular}

Source: 1990 Residential Energy Consumption Survey (DOE 1993).

TABLE 61987 Actual and Estimated Space Heating Shares (percent) by Income Category

\begin{tabular}{lccccccc}
\hline & \multicolumn{3}{c}{ Natural Gas } & & \multicolumn{3}{c}{ Electricity } \\
\cline { 2 - 4 } \cline { 7 - 8 } Income Category & Actual & Estimated & $\begin{array}{c}\text { Percent } \\
\text { Deviation }\end{array}$ & & Actual & Estimated & $\begin{array}{c}\text { Percent } \\
\text { Deviation }\end{array}$ \\
\hline Quintile One & 55.81 & 56.81 & 1.79 & & 16.59 & 20.19 & 21.70 \\
Quintile Two & 54.96 & 56.79 & 3.33 & & 18.26 & 20.51 & 12.32 \\
Quintile Three & 54.56 & 58.85 & 7.86 & & 18.25 & 18.99 & 4.05 \\
Quintile Four & 52.75 & 59.02 & 11.89 & & 23.65 & 18.89 & $(20.13)$ \\
Quintile Five & 58.09 & 60.98 & 4.98 & & 22.23 & 17.93 & $(19.34)$ \\
\hline
\end{tabular}

Source: 1987 Residential Energy Consumption Survey (DOE 1990). 
TABLE 71987 Actual and Estimated Water Heating Shares (percent) by Income Category

\begin{tabular}{lccccccc}
\hline & \multicolumn{3}{c}{ Natural Gas } & & \multicolumn{3}{c}{ Electricity } \\
\cline { 2 - 4 } \cline { 7 - 8 } Income Category & Actual & Estimated & $\begin{array}{c}\text { Percent } \\
\text { Deviation }\end{array}$ & & Actual & Estimated & $\begin{array}{c}\text { Percent } \\
\text { Deviation }\end{array}$ \\
\hline Quintile One & 54.16 & 52.98 & $(2.18)$ & & 34.00 & 36.89 & 8.50 \\
Quintile Two & 51.82 & 53.98 & 4.17 & & 39.08 & 35.79 & $(8.42)$ \\
Quintile Three & 54.10 & 55.80 & 3.14 & & 35.68 & 33.92 & $(4.93)$ \\
Quintile Four & 51.98 & 56.18 & 8.08 & & 38.00 & 32.95 & $(13.29)$ \\
Quintile Five & 59.96 & 59.16 & $(1.33)$ & & 29.89 & 29.60 & $(0.97)$ \\
\hline
\end{tabular}

Source: 1987 Residential Energy Consumption Survey (DOE 1990). 


\section{REFERENCES}

DOE - see U.S Department of Energy.

Judge, G.G., et al., 1985, The Theory and Practice of Econometrics, Second Edition, John Wiley and Sons, New York, N.Y.

Maddala, G.S., 1983, Limited Dependent and Qualitative Variables in Econometrics, Cambridge University Press, London, England.

SHAZAM User's Reference Manual Version 7.0, 1993, ISBN 0-07-069862-7, McGraw-Hill, New York, N.Y.

U.S. Department of Energy, 1990, 1987 Residential Energy Consumption Survey, Energy Information Administration, public-use data tape, Washington, D.C.

U.S. Department of Energy, 1993, 1990 Residential Energy Consumption Survey, Energy Information Administration, public-use data tape, Washington, D.C.

U.S. Department of Energy, 1994, Model Documentation Report: Residential Sector Demand Module of the National Energy Modeling System, DOE/EIA-M067, Washington, D.C. 